Volume 71 of the Yale Series of Younger Poets 
This page intentionally left blank 
CAROLYN FORCHE

\section{Gathering the Tribes}

FOREWORD BY STANLEY KUNITZ

Yale University Press

New Haven and London 
Centenary Edition, 2019

Published with assistance from a grant to honor James Merrill.

Originally published in 1976 by Yale University Press with assistance from the Mary Cady Tew Memorial Fund.

Copyright (C) I976 by Carolyn Forché.

All rights reserved. This book may not be reproduced, in whole or in part, in any form

(beyond that copying permitted by Sections 107 and 108 of the U.S. Copyright Law and except by reviewers for the public press), without written permission from the publishers.

Library of Congress catalog card number: 75-32672 ISBN: 978-0-300-24632-2 (paperback : alk. paper)

Designed by Sally Sullivan and set in Monotype Bembo type by Michael \& Winifred Bixler, Boston, Massachusetts. Printed in the United States of America.

Yale University Press books may be purchased in quantity for educational, business, or promotional use. For information, please e-mail sales.press@yale.edu (U.S. office) or sales@yaleup.co.uk (U.K. office).

This paper meets the requirements of ANSI/NISO Z39.48-I992 (Permanence of Paper).

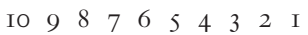


for my parents

and grandparents 
This page intentionally left blank 